\title{
KAJIAN PERUBAHAN MUTU KESEGARAN IKAN TONGKOL (Euthynnus Affinis) YANG DIRENDAM DALAM EKSTRAK RUMPUT LAUT (Eucheuma spinosum) DAN EKSTRAK BUAH BAKAU (Sonneratia alba)
}

\author{
Anggriani Fedrika Pianusa ${ }^{1}$, Grace Sanger ${ }^{2}$ dan Djuhria Wonggo ${ }^{2}$ \\ 1) Mahasiswa pada Program Studi Teknologi Hasil Perikanan FPIK Unsrat Manado \\ 2) Staf pengajar pada Program Studi Teknologi Hasil Perikanan FPIK Unsrat Manado \\ Email: adelia.niomba@yahoo.com
}

\begin{abstract}
The research has been done to know the influence of seaweed extract (Eucheuma spinosum) and mangrove fruit extract (Sonneratia alba) as antibacterial in preserving tongkol fish. Seaweed (Eucheuma spinosum) and mangrove fruit (Sonneratia alba) were refined, filtered, and dissolved into sterile aquades. Fresh tongkol fish soaked in that extract added ice to maintain the temperature not more than 5 celsius degree. Observation was done to chemistry characteristic $(\mathrm{pH})$, there was microbe pollution (ALT) and sensory characteristic and hedonic of tongkol fish produced by using score test. The result of observation to the sensory value and hedonic of tongkol fish which soaked in each extract give very real influence. On the other side, treatment of soak in extract did not give real influence to $\mathrm{pH}$ and microbe pollution (ALT).
\end{abstract}

\begin{abstract}
Keyword: Euthynnus affinis, Eucheuma spinosum, Sonneratia alba.
Telah dilakukan penelitian untuk mengetahui pengaruh dari ekstrak rumput laut Eucheuma spinosum dan ekstrak buah bakau Sonneratia alba sebagai antibakteri dalam mengawetkan ikan tongkol. Rumput laut Eucheuma spinosum dan buah bakau Sonneratia alba dihaluskan, disaring dan dilarutkan ke dalam aquades steril. Ikan tongkol segar direndam dalam ekstrak tersebut sambil diberi es dengan mempertahankan suhu agar tidak lebih dari $5^{\circ} \mathrm{C}$. Pengamatan dilakukan terhadap sifat kimia $(\mathrm{pH})$, adanya cemaran mikroba (ALT) dan sifat sensori dan hedonik ikan tongkol yang dihasilkan dengan menggunakan uji skor. Hasil pengamatan terhadap nilai sensori dan hedonik ikan tongkol yang direndam dalam masing-masing ekstrak memberikan pengaruh yang sangat nyata. Sebaliknya perlakuan perendaman dalam ekstrak tidak memberikan pengaruh yang nyata terhadap $\mathrm{pH}$ dan cemaran mikroba (ALT).
\end{abstract}

Kata Kunci: Euthynnus affinis, Eucheuma spinosum, Sonneratia alba.

\section{PENDAHULUAN}

Proses pengawetan ikan merupakan salah satu bagian penting dari mata rantai industri perikanan, dimana pengawetan bertujuan mempertahankan kesegaran ikan selama mungkin dengan cara menghambat penyebab kemunduran mutu. Perubahan mutu kesegaran dapat berlangsung secara enzimatis, kimia dan bakteriologi dengan diikuti penurunan organoleptik yang dipengaruhi oleh keadaan temperatur, dimana semakin tinggi suhu, semakin cepat pula penurunan mutu kesegaran (Afrianto dan Liviawaty, 1989). Untuk mempertahankan mutu kesegaran dapat dilakukan penanganan dengan menggunakan es dan bahan pengawet alami untuk mempertahankan kesegaran ikan. Pendinginan dengan es umumnya ditujukan untuk memasarkan ikan dalam keadaan basah dengan menurunkan suhu pusat daging ikan $-1--2^{\circ} \mathrm{C}$, dimana penerapan suhu rendah dapat mempertahankan nilai kesegaran ikan (Ilyas, 1983).

Eucheuma spinosum adalah salah satu jenis rumput laut dari kelas Rhodophyceae (ganggang merah) yang memiliki permukaan licin, berwarna cokelat tua hingga cokelat muda, hijau kuning, atau merah ungu, tingginya dapat mencapai $30 \mathrm{~cm}$. Senyawa fenol dan turunannya (flavonoid) yang terdapat pada rumput laut $E$. spinosum merupakan salah satu antibakteri yang bekerja dengan mengganggu fungsi membran sitoplasma bakteri (Fattah, 2003).

Sonneratia alba adalah salah satu jenis buah bakau yang berbentuk bola, dengan 
ukuran $3 \times 4 \mathrm{~cm}$, berbiji banyak, dengan pangkal terlindung kelopak yang tidak rontok dan tidak akan membuka pada saat telah matang (Tjitrosoepomo, 1999 dalam Maryani, dkk. 2002). S. alba mengandung senyawa yang dapat menghambat pertumbuhan bakteri seperti: silitol, polyol, sukrosa, tannin, sterol, triterpenoid, mineral dan nukleotida, dan 24 jenis senyawa fitokimia yang terdiri terdiri dari 8 steroid, 9 triterpen, 3 flavonoid dan 4 turunan karboksil benzene (Varghese, et al. 2010 dalam Hamzah, 2013).

Kekhawatiran terhadap efek samping penggunaan bahan pengawet sintetik yang tersedia dipasaran saat ini sebagai antioksidan maupun antibiotik, maka bahan alami menjadi alternatif yang terpilih. Senyawa bioaktif bahan alami mampu melindungi bahan pangan terhadap kerusakan yang disebabkan oleh serangan bakteri. Alga laut Euchema spinosum dan buah bakau Soneratia alba merupakan sumber bioaktif bahan alami yang banyak tumbuh diperairan Indonesia.

\section{METODOLOGI PENELITIAN}

Alat-alat yang digunakan adalah termometer, plastik es, pisau, sarung tangan, talenan, coolBox, pipet ukur $1 \mathrm{ml}$, meja kerja, timbangan analitik, blender, inkubator, gelas ukur, lampu spritus, erlenmeyer $1000 \mathrm{ml}$ dan $250 \mathrm{ml}$, cawan petri, autoclave, $\mathrm{pH}$ meter, magnetic stirrer, wajan, meja dan alat tulis menulis.

Bahan-bahan yang digunakan adalah Ikan Tongkol (Euthynus affinis) dengan berat kira-kira 250 gr per ekor, Rumput Laut Euchema spinosum segar dan Buah Sonneratia alba segar, akuades, NaCL 9\% , Nutrien Agar, Alkohol 70\% dan 95\%.

Penelitian ini bersifat eksperimen, perlakuan yang dilakukan adalah perlakuan tanpa ekstrak, ekstrak rumput laut Eucheuma spinosum dan ekstrak buah bakau Sonneratia alba dengan perlakuan lama perendaman ikan tongkol dalam ekstrak dengan mempertahankan suhu antara $0-5^{\circ} \mathrm{C}$. Data yang dihasilkan dianalisis secara statistik menggunakan Rancangan Acak Kelompok (RAK) dalam faktorial dengan ulangan sebanyak 2 kali $(3 \times 4 \times 2)$. Perlakuan yang memberikan pengaruh yang nyata (signifikan) diuji lanjut menggunakan uji Beda Nyata Terkecil (BNT) untuk melihat perbedaan setiap perlakuan yang berpengaruh nyata.
Tata laksana dalam penelitian ini diawali dengan membeli ikan tongkol segar di pasar Bahu kemudian dimasukkan kedalam coolbox dengan perbandingan es dan ikan 2:1 dibawa ke Laboratorium Teknologi Penanganan dan Pengolahan Hasil Perikanan untuk diberi perlakuan yang terdiri dari: perendaman tanpa menggunakan ekstrak sebagai kontrol $\left(\mathrm{A}_{1}\right)$, perendaman dalam ekstrak rumput laut $E$. spinosum $\left(\mathrm{A}_{2}\right)$ dan perendaman dalam ekstrak buah bakau $\left(\mathrm{A}_{3}\right)$. Perlakuan penyimpanan terdiri dari 0 hari $\left(B_{1}\right), 2$ hari $\left(B_{2}\right)$, 4 hari $\left(B_{3}\right)$ dan 6 hari $\left(\mathrm{B}_{4}\right)$.

Untuk rumput laut, rumput laut dicuci terlebih dahulu sampai bersih menggunakan air yang mengalir, kemudian dipotong-potong dan dihaluskan dengan cara diblender, sedangkan untuk buah bakau, setelah buah bakau dicuci bersih dan dipotong-potong harus dijemur terlebih dahulu dengan cara diangin-anginkan sebelum dihaluskan. Rumput laut dan buah bakau yang telah dihaluskan, disaring dan dilarutkan dalam akuades steril dan dilakukan perendaman selama 24 jam dengan perbandingan akuades, ekstrak 2:1. Ikan tongkol segar di masukan ke dalam ekstrak tersebut sambil diberi es dengan mempertahankan suhu agar tidak lebih dari $5^{\circ} \mathrm{C}$, dengan lama penyimpanan $0,2,4$ dan 6 hari dalam coolbox. Kemudian dilakukan pengukuran terhadap kualitas mutu yang terdiri dari: Derajat Keasaman ( $\mathrm{pH})$, Angka Lempeng Total (ALT) dan Organoleptik.

\section{HASIL DAN PEMBAHASAN}

\section{Angka Lempeng Total}

Secara keseluruhan terjadi peningkatan nilai ALT pada semua jenis ekstrak selama penyimpanan dingin. Namun dngan adanya bahan alami antibakteri dapat menghambat pertumbuhan bakteri. Untuk mengetahui pengaruh perlakuan ekstrak (A) dan lama penyimpanan (B) terhadap nilai ALT, maka dilakukan analisa sidik ragam dimana untuk perlakuan ekstrak memberikan pengaruh yang tidak nyata $(P<0,01$ dan 0,05), sedangkan untuk perlakuan lama penyimpanan memberikan pengaruh yang nyata $(P>0,05)$. Berdasarkan data tersebut maka perlu untuk dilakukan uji lanjut untuk perlakuan lama penyimpanan. Hasil uji lanjut BNT untuk perlakuan lama penyimpanan memberikan pengaruh yang nyata $(P>0,05)$. Histogram nilai ALT ikan tongkol yang direndam tanpa 
menggunakan ekstrak, ekstrak E. spinosum dan ekstrak buah $S$. alba pada penyimpanan dingin selama 0, 2, 4 dan 6 hari dapat dilihat pada Gambar 1.

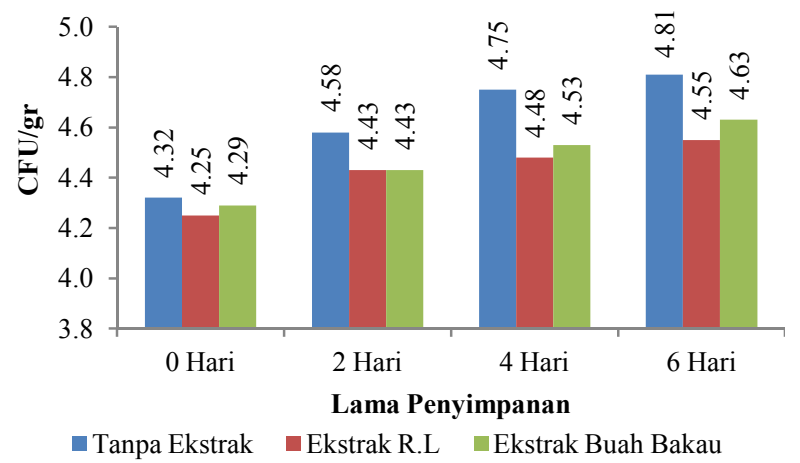

Gambar 1. Nilai ALT (CFU/gr) Ikan Tongkol Selama Penyimpanan Dingin.

Ikan tongkol yang direndam tanpa menggunakan ekstrak selama penyimpanan dingin mengalami peningkatan dengan nilai ALT sebesar 4,81. Hal ini dikarenakan terdapat beberapa bakteri yang walaupun pada suhu dingin masih hidup dan karena tidak adanya penambahan bahan alami antibakteri yang dapat menghambat bahkan membunuh bakteri yang ada pada ikan tongkol.

Ikan tongkol yang direndam dalam ekstrak E. spinosum mempunyai nilai rata-rata ALT 4,55 CFU/gr. Dengan adanya penambahan ekstrak E. spinosum dapat menghambat pertumbuhan bakteri. Menurut Haniffa, $d k k$ (2012), flavonoid pada E. spinosum merupakan senyawa fenol yang berfungsi sebagai antibakteri dengan cara membentuk senyawa kompleks terhadap protein ekstraseluler yang mngganggu intergritas membran dan dinding sel.

Untuk ikan tongkol yang direndam dalam ekstrak buah baku $S$. alba mempunyai nilai ALT 4,63 CFU/gr. Adanya penambahan ekstrak buah $S$. alba mampu mneghambat pertumbuhan bakteri sehingga peningkatan bakteri selama masa penyimpanan dapat dihambat. Hal ini diperkuat oleh pernyataan Govindasamy (2008) dalam Netty, dkk (2013) bahwa bakau mengandung lebih banyak polyphenol dibandingkan dengan tumbuhan halofit. Senyawa polyphenol dikenal memiliki berbagai aktivitas biologik termasuk antibakteri.

Berdasarkan SNI 01-2729-2-2006 batas maksimal nilai ALT pada ikan segar adalah $5 \times 10^{5}$ Koloni/gr (Nilai Log maksimal 5,7
CFU/gr). Secara keseluruhan hasil pengujian nilai ALT masing-masing masih di bawah maksimal. Berdasarkan pernyataan tersebut maka ikan tongkol yang direndam menggunakan ekstrak dan tanpa ekstrak hingga hari ke 6 masih dapat dikategorikan segar dan masih bisa untuk diolah lanjut.

\section{pH (Tingkat Keasaman)}

$\mathrm{pH}$ ikan tongkol baik yang menggunakan ekstrak maupun tanpa menggunakan ekstrak selama penyimpanan dingin mengalami peningkatan, namun masih dapat dihambat oleh adanya bahan alami antibakteri. Perlakuan penambahan ekstrak pada ikan tongkol mempunyai nilai $\mathrm{pH}$ yang lebih baik dibandingkan dengan yang tidak menggunakan ekstrak. Untuk mengetahui pengaruh perlakuan ekstrak (A) dan lama penyimpanan (B) terhadap nilai $\mathrm{pH}$ dilakukan analisa sidik ragam. Berdasarkan hasil analisa sidik ragam untuk perlakuan jenis ekstrak dan lama penyimpanan memberikan pengaruh yang tidak nyata $(\mathrm{P}<0,01$ dan 0,05$)$. Histogram nilai $\mathrm{pH}$ ikan tongkol yang direndam tanpa menggunakan ekstrak, ekstrak E. spinosum dan ekstrak buah $S$. alba selama penyimpanan dingin pada 0,2 4 dan 6 hari dapat dilihat pada Gambar 2.

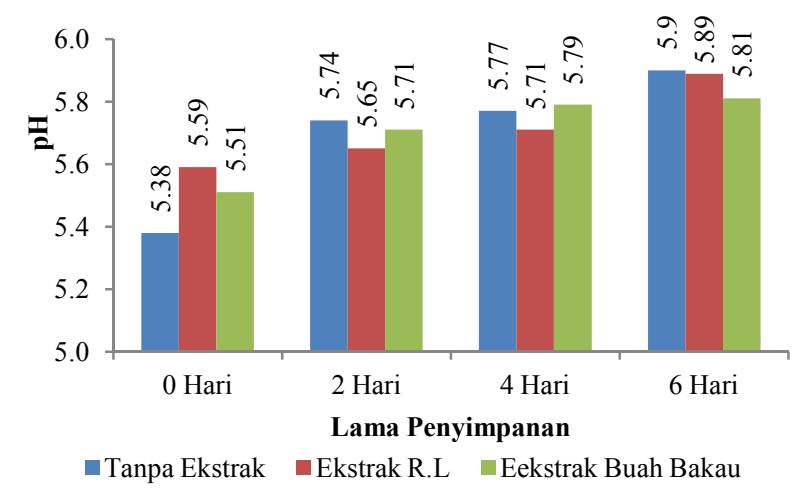

Gambar 2. Nilai pH Ikan Tongkol Selama Penyimpanan Dingin.

Ikan tongkol yang direndam tanpa mengguankan ekstrak mempunyai nilai $\mathrm{pH}$ 5,95. Terjadinya peningkatan nilai $\mathrm{pH}$ dikarenakan adanya masa penyimpanan. Menurut Eskin (1990) dalam Milo (2013), penurunan $\mathrm{pH}$ terjadi karena pada saat ikan baru mati terjadi penurunan ATP dan keratin fosfat melalui proses aktif glikolisi, dimana glikolisis mengubah glikogen menjadi asam laktat yang menyebabkan terjadinya penurunan $\mathrm{pH}$. Naiknya nilai $\mathrm{pH}$ menunjukkan adanya 
aktivitas pertumbuhan bakteri pembusuk oleh aksi sejumlah enzim pada jaringan ikan yang menghasilkan amoniak Destrosier (1987).

Pada ikan tongkol yang direndam dalam ekstrak E. spinosum mempunyai nilai pH 5,89. Pertumbuhan bakteri berdasarkan nilai $\mathrm{pH}$ masih dapat dihambat oleh adanya senyawa antibakteri pada ekstrak E. spinosum dibandingkan dengan ikan tongkol yang direndam tanpa menggunakan ekstrak. Hal ini diperkuat oleh pernyataan Fattah (2013), bahwa ekstrak etanol dan metanol pada rumput laut $E$. spinosum mempunyai daya hambat yang besar terhadap pertumbuhan bakteri.

Untuk Ikan tongkol yang direndam dalam ekstrak buah $S$. alba mempunyai nilai $\mathrm{pH}$ 5,81. Adanya penambahan bahan alami antibakteri dari ekstrak buah $S$. alba dapat menghambat pertumbuhan bakteri, dimana menurut Vikram, dkk (1999) dalam Naiborhu (2002) senyawa flavonoid pada buah S. alba mampu mengubah berbagai proses fisiologi dari bakteri untuk menghambat pertumbuhannya, diantaranya adalah dengan menghambat pembentukan biofilm pada $V$. harveyi yang digunakan untuk perlindungan diri.

Berdasarkan hasil penelitian terhadap nilai $\mathrm{pH}$ ikan tongkol baik yang direndam dalam ekstrak maupun yang tidak menggunkan ekstrak masih tidak berpengaruh terhadap perubahan nilai $\mathrm{pH}$ ikan tongkol. Menurut Munandar, $d k k$ (2009) nilai $\mathrm{pH}$ merupakan salah satu indikator yang digunakan untuk menentukan tingkat kesegaran ikan

\section{Organoleptik Insang}

Sebagian besar nilai organoleptik insang terjadi penurunan dari hari ke 0 sampai sampai hari ke 6 , namun dengan adanya penambahan bahan alami antibakteri dapat menghambat pertumbuhan bakteri. Untuk mengetahui pengaruh perlakuan jenis ekstrak dan perlakuan lama penyimpanan (AB) terhadap nilai organoleptik mata, maka dilakukan analisa sidik ragam. Berdasarkan hasil analisa sidik ragam menunjukan bahwa untuk perlakuan jenis ekstrak memberikan pengaruh yang tidak nyata $(\mathrm{P}<0,01$ dan 0,05$)$ sedangkan untuk perlakuan lama penyimpanan memberikan pengaruh yang sangat nyata $(\mathrm{P}>0,01$ dan 0,05$)$. Berdasarkan hasil tersebut maka dilakukan uji lanjut BNT untuk perlakuan A. Hasil uji lanjut tersebut menunjukan bahwa untuk perlakuan B memberikan pengaruh yang sangat nyata. Histogram nilai organoleptik insang ikan tongkol yang direndam tanpa menggunakan ekstrak, ekstrak E. spinosum dan ekstrak buah $S$. alba selama $0,2,4$ dan 6 hari penyimpanan dingin dapat dilihat pada Gambar 3.

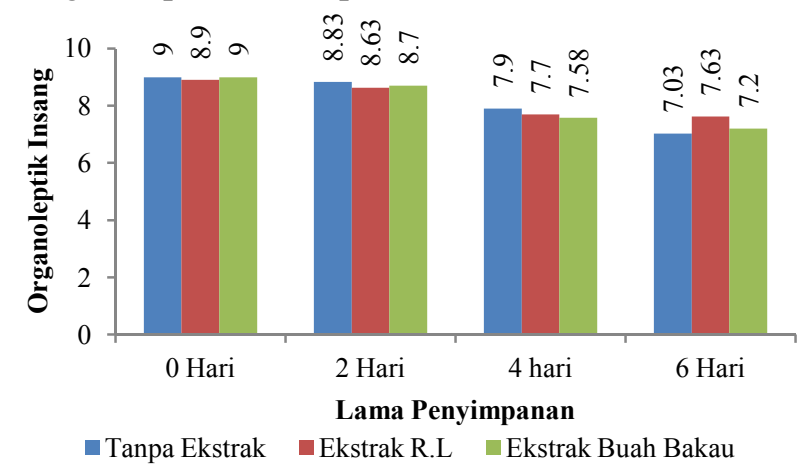

Gambar 3. Nilai Organoleptik Insang Ikan Tongkol Selama Penyimpanan Dingin.

Gambar 3 menunjukan bahwa sebagian besar nilai organoleptik insang terjadi penurunan dari hari ke 0 sampai hari ke 6 . Namun dengan adanya penambahan bahan alami antibakteri dapat menghambat pertumbuhan bakteri. Pada ikan tongkol yang di rendam tanpa menggunakan ekstrak nilai organoleptik insang adalah 7,03. Terjadinya penurunan nilai rata-rata yang lebih cepat pada insang ikan tongkol yang direndam tanpa menggunakan ekstrak karena tidak adanya penambahan bahan alami antibakteri yang dapat menghambat atau membunuh bakteri yang terdapat pada insang. Perubahan pada insang juga dapat dilihat pada penyimpanan hari ke 6 , dimana insang mulai timbul kepudaran warna dari merah mudah ke merah cokelat, tampak agak berlendir dan bau asam lebih nyata Berhimpon, $d k k$ (2002).

Ikan tongkol yang direndam dalam ekstrak E. spinosum mempunyai nilai organoleptik insang sebesar 7,63. Adanya penambahan bahan alami antiakteri dapat menghambat pertumbuhan bakteri pada insang, dimana nilai insang untuk ikan tongkol yang direndam dalam ekstrak E. spinosum masih lebih rendah dibandingkan dengan ikan tongkol yang direndam tanpa menggunakan ekstrak. Menurut Hakim, $d k k$ (2015) flavonoid pada $E$. spinosum merupakan senyawa fenol yang berfungsi sebagai antibakteri dengan cara membentuk senyawa kompleks terhadap protein ekstraseluler. Pada ikan tongkol yang direndam 
dalam ekstrak buah $S$. alba mempunyai nilai organoleptik insang sebesar 7,2. buah bakau $S$. alba dapat menghambat pertumbuhan bakteri. Hal ini diperkuat oleh pernyataan Firdaus (2003), bahwa ekstrak $S$. alba dapat menghambat pertumbuhan bakteri Aeromonas hydrophila. Berdasarkan hasil penelitian pada ikan tongkol yang direndam tanpa menggunakan ekstrak, menggunakan ekstrak $E$. spinosum dan ekstrak buah $S$. alba, selama penyimpanan dingin 0,24 dan 6 hari, mengacu pada standar mutu ikan segar berdasarkan SNI 01-2729.1-2006, masih memenuhi syarat nilai organoleptik, sehingga masih layak untuk dikonsumsi.

\section{Mata}

Mata merupakan indikator kesegaran utama yang dilihat oleh konsumen saat membeli ikan segar. Selama penyimpanan dingin terjadi peningkatan pada nilai organoleptik mata, namun masih dapat dihambat oleh adanya bahan alami antibakteri. Untuk mengetahui pengaruh perlakuan jenis ekstrak dan lama penyimpanan $(\mathrm{AB})$ terhadap nilai organoleptik mata, maka dilakukan analisa sidik ragam. Berdasarkan hasil analisa sidik ragam semua jenis perlakuan memberikan pengaruh yang berbeda sangat nyata $(\mathrm{P}>0,01$ dan 0,05$)$. Dari hasil tersebut maka dilakukan uji lanjut BNT, dimana hasil uji lanjut menunjukan bahwa semua jenis perlakuan memberikan pengaruh yang berbeda sangat nyata $(\mathrm{P}>0,01$ dan 0,05$)$. Histogram nilai organoleptik mata ikan tongkol yang direndam tanpa ekstrak, ekstrak $E$. spinosum dan ekstrak buah $S$. alba selama 0,2 , 4 dan 6 hari penyimpanan dingin dapat dilihat pada Gambar 4.

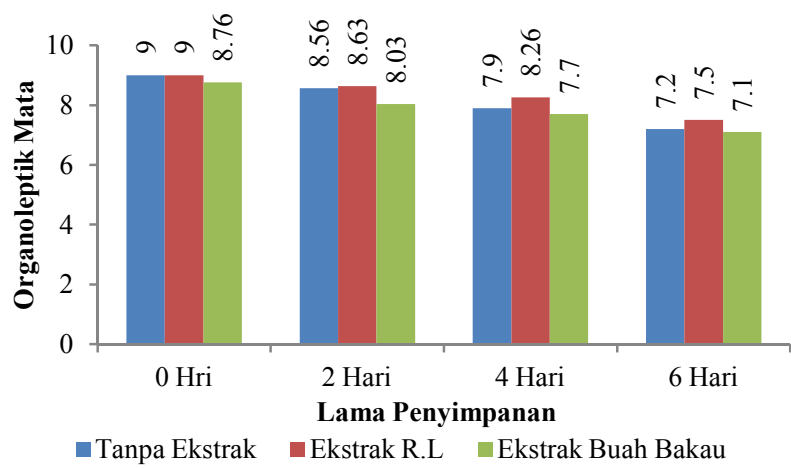

\section{Gambar 4. Nilai Organoleptik Mata Ikan Tongkol Selama Penyimpanan Dingin.}

Ikan tongkol yang direndam tanpa menggunakan ekstrak mengalami peningkatan selama penyimpanan dengan nilai 7,2. Adanya perubahan organoleptik mata pada penyimpanan hari ke 6, dikarenakan mata ikan tongkol sudah mengalami kemunduran mutu yang disebabkan oleh pertumbuhan bakteri pembususk, yang ditandai dengan bola mata yang cekung, pupil putih susu dan kornea keruh. Hal ini diperkuat oleh pernyataan Ilyas (1983), bahwa salah satu akibat dari mulai berkembangnya bakteri adalah mata jadi terbenan dan pudar sinarnya.

Pada ikan tongkol yang direndam dalam ekstrak E. spinosum juga mengalami penurunan nilai organoleptik mata sebesar 7,5. Menurut Parubak (2013) senyawa fenol yang terkandung dalam rumput laut mempengaruhi nilai organoleptik penampakan mata, sehingga sangat cepat terjadi perubahan pada mata ikan. Adanya penambahan ekstrak E. spinosum dapat mengahambat pertumbuhan bakteri. Untuk Ikan tongkol yang direndam menggunakan ekstrak buah $S$. alba penurunan nilai organoleptik mata sebesar 7,1. Menurut Agati, dkk (2007) dalam Herawati (2011) permeabilitas membran sel pada mata ikan terganggu akibat adanya senyawa fenol dan tannin pada ekstrak $S$. alba.

Berdasarkan hasil penelitian dapat dilihat bahwa pemanfatatan beberapa bahan alami pada proses penanganan ikan akan memberikan efek terhadap kenampakan mata ikan. Pemanfaatan E. spinosum dan buah $S$. alba memberikan pengaruh pada mata ikan sehingga mata ikan agak keruh dan berwarna. Mengacu pada standar mutu ikan segar berdasarkan SNI 01-2729-2-2006, kenampakan mata ikan tongkol yang direndam tanpa menggunakan ekstrak, ekstrak E. spinosum dan $S$. alba selama $0,2,4$ dan 6 hari pada penyimpanan dingin masih memenuhi persyaratan.

\section{Bau}

Bau ikan tongkol selama penyimpanan dingin mengalami peningkatan, namun masih dapat dihambat oleh adanya bahan alami anti bakteri. Untuk mengetahui pengaruh perlakuan jenis ekstrak (A) dan perlakuan lama penyimpanan (B) terhadap nilai organoleptik bau, maka dilakukan analisa sidik ragam yang hasilnya memberikan pengaruh yang berbeda sangat nyata $(\mathrm{P}>0,01$ dan 0,05$)$ terhadap perlakuan ekstrak dan lama penyimpanan. Dari 
hasil tersebut maka dilakukan uji lanjut BNT. Berdasarkan hasil uji BNT perlakuan jenis ekstrak dan untuk perlakuan lama penyimpanan juga memberikan pengaruh yang berbeda sangat nyata $(\mathrm{P}>0,01$ dan 0,05$)$.

Histogram nilai organoleptik bau ikan tongkol yang direndam tanpa ekstrak, ekstrak $E$. spinosum dan ekstrak buah $S$. alba selama 0,2 , 4 dan 6 hari penyimpanan dingin dapat dilihat pada Gambar 5.

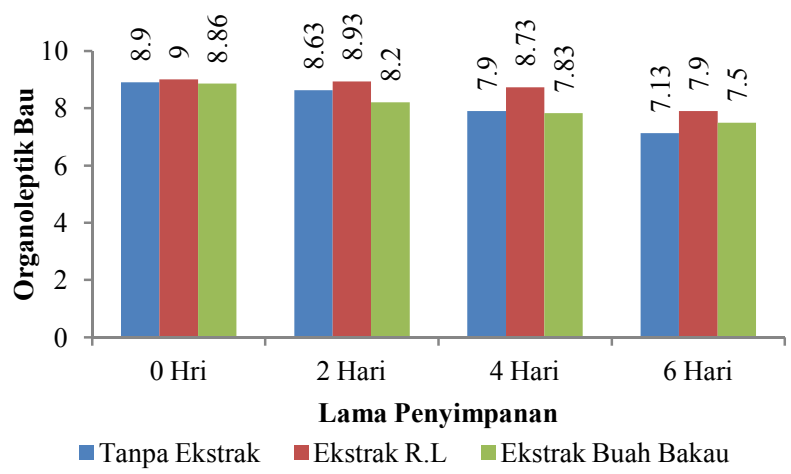

\section{Gambar 5. Nilai Organoleptik Bau Ikan Tongkol Selama Penyimpanan Dingin.}

Ikan tongkol yang direndam tanpa menggunakan ekstrak selama penyimpanan dingin mengalami penurun dengan nilai 7,13 . Terjadinya perubahan bau pada penyimpanan hari ke 6 dikarenakan adanya pertumbuhan bakteri, dimana bau segar/bau rumput laut dari ikan tongkol sudah mulai menghilang. Menurut Junianto (2003), perubahan yang terjadi pada bau ikan karena penguraian protein dari aktivitas bakteri, sehingga hubungan antara jumlah bakteri dengan bau pada ikan berbanding lurus.

Ikan tongkol yang direndam dalam ekstrak E. spinosum mempunyai nilai organoleptik bau sebesar 7,9. Adanya penambahan ekstrak E. spinosum hanya membuat bau dari ikan tongkol menjadi netral (tidak berbau rumput laut), dan masih dikategorikan segar, hal ini diperkuat oleh pernyataan Yunus, $d k k$ (2009), bahwa ekstrak rumput laut $E$. spinosum mampu berperan sebagai antibakteri terhadap bakteri Aeromonas hydrophila.

Ikan tongkol yang direndam dalam ekstrak buah $S$. alba selama penyimpanan dingin megalami penurunan dengan nilai 7,5 . Namun dengan adanya penambahan ekstrak $S$. alba membuat bau dari ikan tongkol dapat dihambat sehingga sampai pada penyimpanan hari ke 6 tidak berbau amoniak. Berdasarkan pernyataan Pelczar, et al (1988), bahwa dalam beberapa senyawa kimia yang memiliki sifat sebagai antimikroba diantaranya fenol dengan mekanisme kerja yang merusak dan menenmbus dinding sel bakteri dapat membunuh bakteri.

Ikan tongkol yang direndam pada ekstrak E. spinosum, ekstrak buah $S$. alba, dan tanpa menggunakan ekstrak, terlihat perbedaan yang sangat nyata dimana ikan tongkol yang tidak menggunakan ekstrak selama penyimpanan dingin selama $0,2,4$ dan 6 hari. Pemanfaatan beberapa bahan alami pada proses penanganan ikan akan memberikan efek terhadap kenampakan mata ikan. Mengacu pada standar mutu ikan segar yang berdasarkan SNI 01-2779-2-2006, mata ikan tongkol yang direndam tanpa menggunakan ekstrak, ekstrak E. spinosum dan ekstrak buah $S$. alba selama 0 , 2, 4 dan 6 hari pada penyimpanan dingin masih memenuhi syarat.

\section{Tekstur}

Data hasil pengamatan organoleptik tekstur ikan tongkol yang direndam tanpa menggunakan ekstrak, menggunakan eksrak $E$. spinosum dan ekstrak buah $S$. alba selama 0,2 , 4 dan 6 hari penyimpanan dingin mengalami peningkatan, namun masih dapat dihambat dengan adanya penambahan bahan alami antibakteri. Untuk perlakuan jenis ekstrak (A) dan perlakuan lama penyimpanan (B) terhadap nilai organoleptik tekstur memberikan pengaruh yang berbeda sangat nyata $(\mathrm{P}>0,01$ dan 0,05$)$. Berdasarkan hasil tersebut maka dilakukan uji lanjut BNT, dimana hasil uji BNT menunjukan bahwa perlakuan A dan B memberikan pengaruh yang berbeda sangat nyata.

Histogram nilai organoleptik ikan tongkol yang direndam tanpa menggunakan ekstrak, ekstrak E. spinosum dan ekstrak buah $S$. alba selama $0,2,4$ dan 6 hari penyimpanan dingin dapat dilihat pada Gambar 6 .

Pada ikan tongkol yang direndam tanpa menggunakan ekstrak selama penyimpanan dingin mempunyai nilai organoleptik tekstur sebesar 7,03. Hal ini dikarenakan selama masa penyimpanan perubahan tekstur daging ikan akan berubah karena adanya pertumbuhan bakteri yang mengakibatkan daging ikan tongkol sudah tidak kompak lagi. Hal ini diperkuat oleh pernyataan Suwetja (2011), bahwa penguraian oleh bakteri mulai berlangsung insentif setelah tahap rigormotis 
berlalu, yaitu setelah daging ikan tidak lagi kompak.

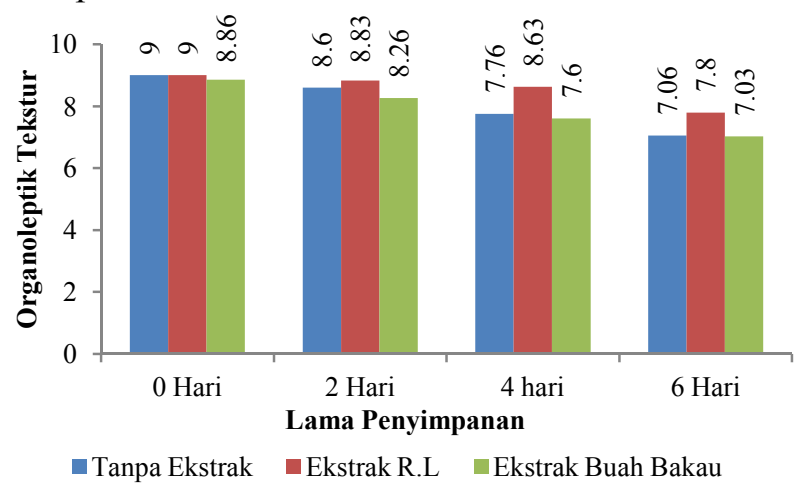

Gambar 6. Nilai Organoleptik Tekstur Ikan Tongkol Selama Penyimpanan Dingin.

Pada ikan tongkol yang direndam dalam ekstrak E. spinosum selama penyimpanan dingin juga mengalami peningkatan dengan nilai 7,8 . Perubahan nilai organoleptik tekstur dapat dilihat dari perubahan tekstur ikan yang pada hari pertama sampai hari ke 4 masih sangat padat saat ditekan tidak meninggalkan bekas jari, namun pada hari ke 6 perubahan tekstur dari ikan tongkol mulai terlihat dari tekstur walaupun daging agak lunak tapi belum meninggalkan bekas jari bila ditekan. Hal ini sesuai dengan pernyataan Fattah (2013), adanya senyawa antibakteri pada ekstrak E. spinosum dapat menghambat pertumbuhan bakteri Vibrio cholera dan Staphylococcus aureus.

Pada ikan tongkol yang direndam dalam ekstrak buah bakau $S$. alba peningaktan nilai organoleptik tekstur sebesar 7,2. Perubahan nilai organoleptik tekstur ikan tongkol dapat dilihat dari perubahan tekstur ikan yang pada hari pertama sampai hari ke 2 masih sangat padat, saat ditekan dan tidak meninggalkan bekas jari, namun pada hari ke 4 sampai hari ke 6 perubahan tekstur dari ikan tongkol mulai terlihat dari tekstur yang sudah tidak padat dan saat ditekan sudah meninggalkan bekas jari. Penggunaan ekstrak buah bakau $S$. alba mampu menghambat pertumbuhan bakteri, sehingga tekstur dari ikan tongkol walaupun daging sudah agak kenyal, namun belum ada bekas jari bila ditekan. Menurut Cowan (1999) dalam Hakim (2015), tannin memiliki aktivitas antibakteri yang berhubungan dengan kemampuannya untuk mengnonaktifkan sel mikroba.

Berdasarkan pernyataan tersebut, ikan tongkol yang direndam menggunakan ekstrak buah bakau $S$. alba dan ekstrak rumput laut Eucheuma spinosum dapat menghambat pertumbuhan bakteri. Peran antibakteri dari ekstrak tersebut dalam proses penguraian daging ikan dapat ditekan dibandingkan dengan ikan tongkol yang direndam tanpa menggunakan ekstrak. Mengacu pada standar mutu ikan segar berdasarkan SNI 01-2729-22006, tekstur ikan tongkol yang direndam tanpa menggunakan ekstrak dan menggunakan ekstrak dari hari ke 0 sampai hari ke 6 masih memenuhi syarat nilai organoleptik.

\section{Hedonik Rasa}

Data hasil pengamatan rasa ikan tongkol kukus yang direndam tanpa menggunakan ekstrak, menggunakan ekstrak E. spinosum dan ekstrak buah $S$. alba selama 0, 2, 4 dan 6 hari penyimpanan dingin mengalami penurunan, namun masih dapat dihambat oleh adanya bahan alami antibakteri. Untuk mengetahui pengaruh perlakuan jenis ekstrak (A) dan perlakuan lama penyimpanan (B) terhadap nilai organoleptik rasa, maka dilakukan analisa sidik ragam yang hasilnya untuk perlakuan jenis ekstrak dan perlakuan lama penyimpanan memberikan pengaruh yang sangat nyata $(\mathrm{P}>0,01$ dan 0,05). Dari hasil tersebut maka dilakukan uji lanjut BNT yang menunjukan bahwa perlakuan A dan B memberikan pengaruh yang berbeda sangat nyata.

Histogram nilai organoleptik ikan tongkol yang direndam tanpa menggunakan ekstrak, ekstrak E. spinosum dan ekstrak buah $S$. alba selama 6 hari penyimpanan dingin dapat dilihat pada Gambar 7.

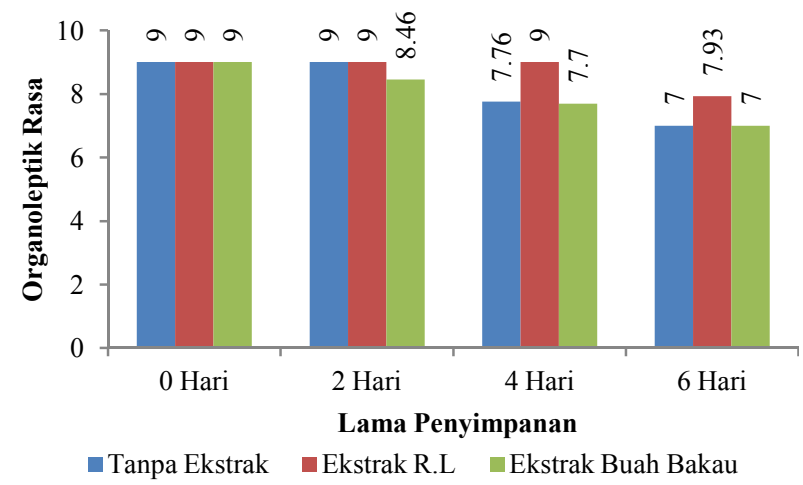

Gambar 7. Nilai Hedonik Rasa Ikan Tongkol Selama Penyimpanan Dingin.

Ikan tongkol yang direndam tanpa menggunakan ekstrak selama penyimpanan dingin mengalami penurunan dengan nilai 7 . Rasa yang berubah pada penyimpanan hari ke 6 
diakibatkan oleh adanya senyawa kimia dan lama penyimpanan yang mengakibatkan terjadinya perubahan rasa dan adanya masa penyimpanan.

Ikan tongkol yang direndam dalam ekstrak E. spinosum juga mengalami penuran selama penyimpanan dingin dengan nilai 7,93 namun masih dapat diterima oleh panelis. Dengan adanya penambahan ekstrak $E$. spinosum tidak membuat perubahan rasa pada ikan tongkol. Hal ini diperkuat oleh pernyataan bahwa rasa merupakan salah satu faktor yang mempengaruhi pilihan konsumen terhadap suatu produk pangan. Semakin banyak penambahan rumput laut dalam pengawetan ikan yang akan diolah lanjut, akan semakin disukai oleh konsumen (Hidayat, 2014).

Ikan tongkol yang direndam dalam ekstrak buah bakau $S$. alba untuk nilai hedonik rasa juga mengalami penurunan dengan nilai 7 . Perubahan nilai hedonik rasa pada ikan tongkol dapat dilihat dari perubahan rasa ikan yang pada hari pertama sampai hari ke 4 masih dapat diterima oleh panelis, namun pada hari 6 rasa dari ikan tongkol sudah tidak terlalu disukai oleh panelis. Perubahan pada rasa terjadi karena adanya kandungan fenol dari buah bakau yang membuat rasa ikan menjadi tidak terlalu enak untuk dikonsumsi. Hal ini diperkuat oleh pernyataan Herawati (2011) bahwa perubahan rasa pada ikan karena adanya senyawa fenol yang terkandung dalam bakau S. alba.

Mengacu pada standar mutu ikan segar berdasarkan SNI 01-2779-2-2006, bahwa rasa ikan tongkol yang direndam tanpa menggunakan ekstrak dan menggunakan ekstrak dari hari ke 0 sampai hari ke 6 masih memenuhi syarat nilai hedonik dan masih layak untuk dikonsumsi.

\section{KESIMPULAN}

Perlakuan ekstrak Eucheuma spinosum dan ekstrak Sonneratia alba tidak memberikan pengaruh yang nyata terhadap hasil analisa ALT dengan nilai 4,63 CFU/gr dan hasil analisa $\mathrm{pH}$ dengan nilai 5,89. Tetapi memberikan pengaruh yang nyata terhadap nilai organoleptik dan nilai hedonik rasa.

\section{SARAN}

Berdasarkan hasil penelitian ini, maka bahan pengawet alami seperti ekstrak rumput laut Eucheuma spinosum dan ekstrak buah bakau Sonneratia alba yang direndam menggunakan es dapat digunakan oleh masyarakat dalam menghambat pertumbuhan mikroba pada ikan agar tidak cepat mengalami kerusakan.

\section{DAFTAR PUSTAKA}

Afrianto dan Liviawaty. 1989. Pengawetan dan Pengolahan Ikan. Kanisius. Yogyakarta 1.

Berhimpon.S., Ijong. F. G., Moniharapon. P. 2002. Penilaian Indera. Penuntun Praktikum. Fakultas Perikanan dan Ilmu Kelautan. Universitas Sam Rtaulangi. Manado.

Badan Standarisasi Nasional. 2006. SNI 01-2729.1-2006. Standar Mutu Ikan Segar. Dewan Standarisasi Indonesia. Jakarta.

Destrosier, N. W., 1987. Teknologi Pengawetan Pangan. Penerjemah Muhji Muljoharjo. UI-press. Jakarta.

Fattah, A., Muslimin, L., Omar S. 2013. Efektifitas Alga Merah (Eucheuma soinosum) Sebagai Antibakteri Patogen Pada Organisme Budidaya Pesisir dan Manusia. Jurnal. Fakultas Ilmu Kelautan dan Perikanan. Universitas Hasanudin. Makasar.

Firdaus L. 2003. Perananan Sonneratia alba Dalam Fermentasi Nira Aren Menjadi Minuman Beralkohol. Marina Chimicsl akta. Jurusann FMIPA. Universitas Hasanuddin. Vol 5. No 28.

Hakim.D. M., Tjahjanngsih. W., Abdillah. A. A. 2015. Pengaruh Ekstrak Alga Merah (Kappaphycus alvareszi) Terhadap Jumlah Total Bakteri Dan Nilai Organoleptik Ikan Kembung (Rastrelliger sp.). Jurnal. Fakultas Perikanan dan Kelautan. Universitas Airlangga. Surabaya. Vol 7. No. 1.

Hamzah. 2013. Karakterisasi Sifat Fisikokimia Tepung Buah Bakau (Sonneratia alba). Skripsi. Jurusan Teknologi Pertanian. Fakultas Pertanian. Universitas Hasanuddin. Makasar. Hal. 22.

Haniffa. M. A., Kavitha, K. (2012). Antibacterial Activity Of Medicinal Herbs Aginst Fish Pathogen Aeromonas hidrophila. Journal of Agricultural Technology, 8 (1): $205-211$.

Herawati. N. 2011. Identifikasi Senyawa Bioaktif Tumbuhan Mangrove Sonneratia alba. Jurnal. Jurusan Kimia. Fakultas Matematika dan Ilu Pengetahuan Alam. Universitas Muhamadya Malang. Malang. Vol. 12. No. 2.

Hidayat N. 2014. Kajian Penggunaan Rumput Laut (Eucheuma cotonii) Sebagai Bahan Tambahan Dalam Pengolahan Ikan Patin (Pangasius hypopthalmus). Jurnal. Fakultas Perikanan dan Ilmu Kelautan. Universitas Riau. Vol. 19 No 2. Hal. 41.

Ilyas, S. 1983. Teknologi Refrigrasi Hasil Perikanan. Jilid 1 Teknik Pembekuan Ikan. CV. Paripurna. Jakarta

Junianto., 2003. Teknik Penangkapan Ikan. Penebar Swadaya. Jakarta.

Maryani. L., Dana D., Sukenda H., 2002. Peranan Ekstrak Kelopak Dan Buah Mangrove (Sonneratia alba) Terhadap Infeksi Bakteri Vibrio harveyi Pada Udang Windu(Panaeus monodon FAB). Jurnal Akuakultur Indonesia. Fakultas Pertanian. Universitas Palangkaraya. Palangkaraya. 
Munandar, A., Nurjanah dan M, Nurimalah. 2009. Kemunduran Mutu Ikan Nila (Oreochromis nioticus) pada Perlakuan Cara kematian dan penyiangan. Jurnal Teknologi Pengolahan Hasil Perikanan Indonesia. XII (2) : $88-101$.

Milo. M. S. 2013. Mutu Ikan Tongkol (Euthynnus affinis) Di Kabupaten Gunung Kidul dan Sleman Daerah Istimewa Yogyakarta. Skripsi. Fakultas Teknobiologi. Universitas Atma Jaya Yogyakarta. Yogyakarta.

Naiborhu. P. E., 2002. Ekstraksi dan Manfaat Ekstrak Mangrove (Sonneratia alba dan Sonneratia caseolaris) Sebagai Bahan Alami Antibakterial Pada : Patogen Udang Windu (Vibrio harveyi). Tesis. Program Pasca Sarjana Institut Pertanian Bogor. Bogor.

Netti, H., Jalaluddin, Daha, L., Firdaus Z. 2013. Sonneratia alba Sebagai Sumber Senyawa Antibakteri
Potensial. Jurnal. Jurusan Kimia FMIPA. Universitas Hasanuddin. Makasar.

Parubak, A. S. 2013. Senyawa Flavonoid Yang Bersifat Antibakteri dari Daun Akway (Drimys becariana. Gibbs). Jurnal. Jurusan Kimia, Fakultas Matematika dan Ilmu Pengetahuan Alam. Universitas Negeri Papua, 6 (1) : 34-37.

Pelczar., M.J, Chan, E.C.S., Kreig, N.R. 1988. Dasar dasar Mikrobiologi 1. Jakarta: UI Press.

Suwetja.I.K., 2011. Biokomia Hasil Perikanan. Media Prima Aksara. Jakarta.

Yunus., Arisandi, A., Abida, I W. 2009. Daya Hambat Ekstrak Metanol Rumput Laut Eucheuma pinosum Terhadap Bakteri Aeromonas hydrophila. Jurnal kelautan 2 (2):16-22. 